Ann. Biol. anim. Bioch. Biophys., 1976, 16 (2), 213-234.

\title{
INFLUENGE OF LH-RF ON LH AND FSH RELEASES IN DOMESTIC MAMMALS
}

\author{
J. PELLETIER \\ Station de Physiologie de la Reproduction, \\ Centre de Recherches de Tours, I. N. R. A., \\ Nouzilly, 37380 Monnaie (France)
}

SUMMARY

Intravenous injection of LH-RF into intact rams induces $\mathrm{LH}$ release into the blood ; this is related to dose. No clear relationship, however, is observed for FSH. LH peak levels appear after a long time (about 2 hours after a roo $\mu \mathrm{g}$ synthetic LH-RF injection); the maximum level is about Io $\mathrm{ng} / \mathrm{ml}$. Conversely, LH-RF injection given to castrated rams has a rapid effect (I0-20 $\mathrm{mn}$ ), and the peak level is much higher then in intact rams $(70-80 \mathrm{ng} / \mathrm{ml})$. This effect is observed as early as 3 hours post-castration. In castrated rams, acute testosterone propionate treatment, given 6 hours before LH-RF, decreases the intensity of LH release by 40 p. Ioo, but does not modify the time needed to reach peak level. On the other hand, chronic testosterone propionate treatment delays the peak level but, in the conditions used, does not modify the magnitude of the $\mathrm{LH}$ peak. Thus, there is may be two different ways in which testosterone acts on $\mathrm{LH}$ release through LH-RF action : I) it decreases LH release after LH-RF ; 2) it delays LH peak time. In the male lamb, LH-RF injection induces $\mathrm{LH}$ patterns which vary with age. At 2o-6o days of age, LH response to LH-RF is immediate, as in castrates; thereafter, there is progressive lengthening of this time, which reaches peak level in the intact adult at I4O days of age. Thus, a kind of maturity of the hypothalamohypophyseal system seems to be achieved only at puberty.

In the ewe, intensity of LH release after LH-RF varies during the estrous cycle according to the plasma $\mathrm{I} 7 \beta$-oestradiol/progesterone ratio, maximum $\mathrm{LH}$ release being observed at day $\mathrm{I} 6$ (IOO p. IOO) and minimum release at day I2 (I3.5 p. IOO). During seasonal anestrus, LH release after LH-RF also varies according to physiological state : in dry ewes LH release is greater (about $4^{\circ} \mathrm{p}$. Ioo) than in post partum lactating or non-lactating ewes.

Influence of LH-RF on LH and FSH releases in other species is discussed in comparison with the above results.

\section{INTRODUCTION}

The determination of the pig Luteinizing Hormone Releasing Factor (LH-RF) sequence (MATsuo et al., I97I) opened a new perspective in the hypothalamo-hypophyseal relationship since SCHALIY's group, almost simultaneously with the achievement of LH-RF purification, presented two statements of utmost importance : 
first, that LH-RF could be involved in both LH and FSH releases (then called LH-RH/FSH-RH) (SCHALLY el al., I97I), and second, that gonadal steroids could modify pituitary responsiveness to LH-RF (ARIMURA and SCHALLY, I97I).

Furthermore, LH-RF presented an evident interest in the control of gonadotropin release for both medical and zootechnical purposes. Hence, the LH-RF effects on FSH and LH releases were investigated in a number of species ; among these, domestic animals, and mainly sheep, appeared convenient subjects for both fundamental and practical studies.

This paper, then, will describe LH-RF effect on LH and FSH releases in sheep, cattle and pig, with frequent reference to other well-studied species, such as rat or man, for comparison and generalization of various concepts.

\section{I. - LH-RF EFFECTS IN INTACT MALE}

Initial studies in ram were carried out with purified sheep LH-RF given in the carotid artery (Amoss and GuILLEMIN, I969). A significant extra LH release occurred as early as $3 \mathrm{mn}$ post-injection, and about $30 \mathrm{mn}$ later, the effect was over. On the contrary, purified TRF was without effect. Injection into the jugular vein of crude acidic extract, equivalent to .5 or r.o hypothalamus, was shown to induce similar LH release (PELLE'TIER, I97I). Purified pig LH-RF was also used to induce LH release in ram, but no correlation with doses was observed (REEvEs et al., I970) in the range of $I$ to $27 \mu \mathrm{g}$. The same group later injected a larger dose of synthetic LH-RF $(250 \mu \mathrm{g})$ into the carotid artery, but a very incomplete $\mathrm{LH}$ pattern was given for one animal only (ARIMURA et al., I972). Even so, it was apparent that maximum plasma $\mathrm{LH}$ value was not reached I hour post-injection. Intravenous injections of LH-RF, ranging from $6.25 \mu \mathrm{g}$ to I $600 \mu \mathrm{g}$, induced a total $\mathrm{LH}$ release (computed from the area under the LH curve) which augmented with increasing LH-RF doses (GALLOWAY, I973) ; LH peak level increased similarly with the dose, and the time to reach this maximum was long (90-I50 $\mathrm{mn}$ ), even for the low doses administered (fig. I $a$ ). Thus, there is a discrepancy between delays in reaching peak level following purified and synthetic LH-RF injection (see above). It is not clearly understood why crude hypothalamic extracts were so efficient since one hypothalamus, including the median eminence, contains about to to $20 \mathrm{ng}$ of L/H-RF (PELLETIER, unpublished results). However, significant LH release was observed following a r25 ng intramuscular injection (Hopkrnson et al., 1974). The same authors pointed out that : a) FSH release was much less sensitive to LH-RF than LH, and b) that with the higher doses of LH-RF tested, the only efficient ones (Io and $50 \mu \mathrm{g}$ ), mean LH release was about twenty times higher than the mean FSH release. In the same samples as those used in GaLLOWAy's study (I973), FSH release was also investigated using a highly specific homologous ovine FSH radioimmunoassay (BLANC, unpublished results). The FSH response to LH-RF was highly variable and generally only oscillations were observed around the mean pre-injection level (fig. 2). Sometimes the response was more accentuated and a clear immediate increase, representing three times the starting level, was obtained. However, no dose-response relationship was observed in the range of $6.25-1.600 \mu \mathrm{g}$ LH-RF (BI,ANC, unpublished results). 
In bull, as in ram, blood LH levels increased when doses of synthetic LH-RF were augmented (ZoLmAN et al., I973; GoLTER et al., I973; Schams et al., I974). Similarly, time elapsed from injection to peak increased with LH-RF, but became

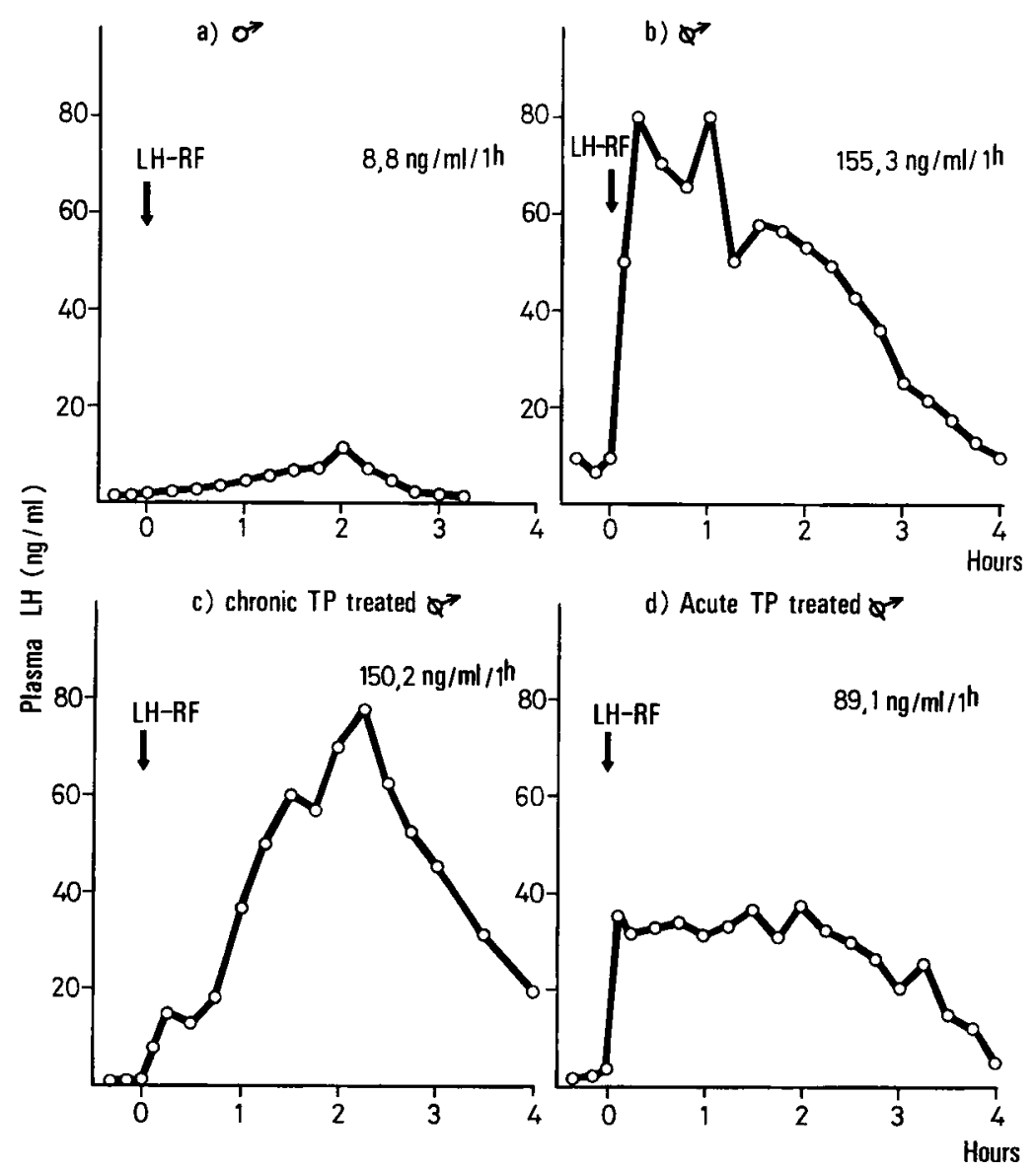

FIG. I. - Effect of intravenous injection of $100 \mu \mathrm{g} L H \cdot R F$ on LH release in :

a) intact rams;

b) long-term castrated rams (over 6 months) ;

c) chronic Testosterone Propionate (TP)-treated rams castrated 3 months before (100 mg TP each other day for I4 days);

d) Long-term castrated rams treated with LH-RF 6 hours after an intramuscular injection of $600 \mathrm{mg}$ TP (from Galloway, 1973; Pelletier, I974 a; Galloway and Pelletier, r975).

stable above Ioo $\mu \mathrm{g} \mathrm{LH}-\mathrm{RF}$ injection in the 90-I40 $\mathrm{mn}$ range. At variance with ram, more obvious FSH release occurred following 62.5 to $500 \mu \mathrm{g}$ LH-RF injections given intramuscularly (Schams et al., I974), peak FSH level reaching three times the pre-injection level.

In male pig, $\mathrm{LH}$ peak was reached IO-I5 $\mathrm{mn}$ after injection, in the range of 0.05 to $2.0 \mu \mathrm{g}$ LH-RF/kg body weight, as in the preceding species (EILLENDORFF 
et al., I973; Pomerantz et al., I974). These LH peaks did not exceed four times the basal level, and thus they differed markedly from those observed in ram and bull.
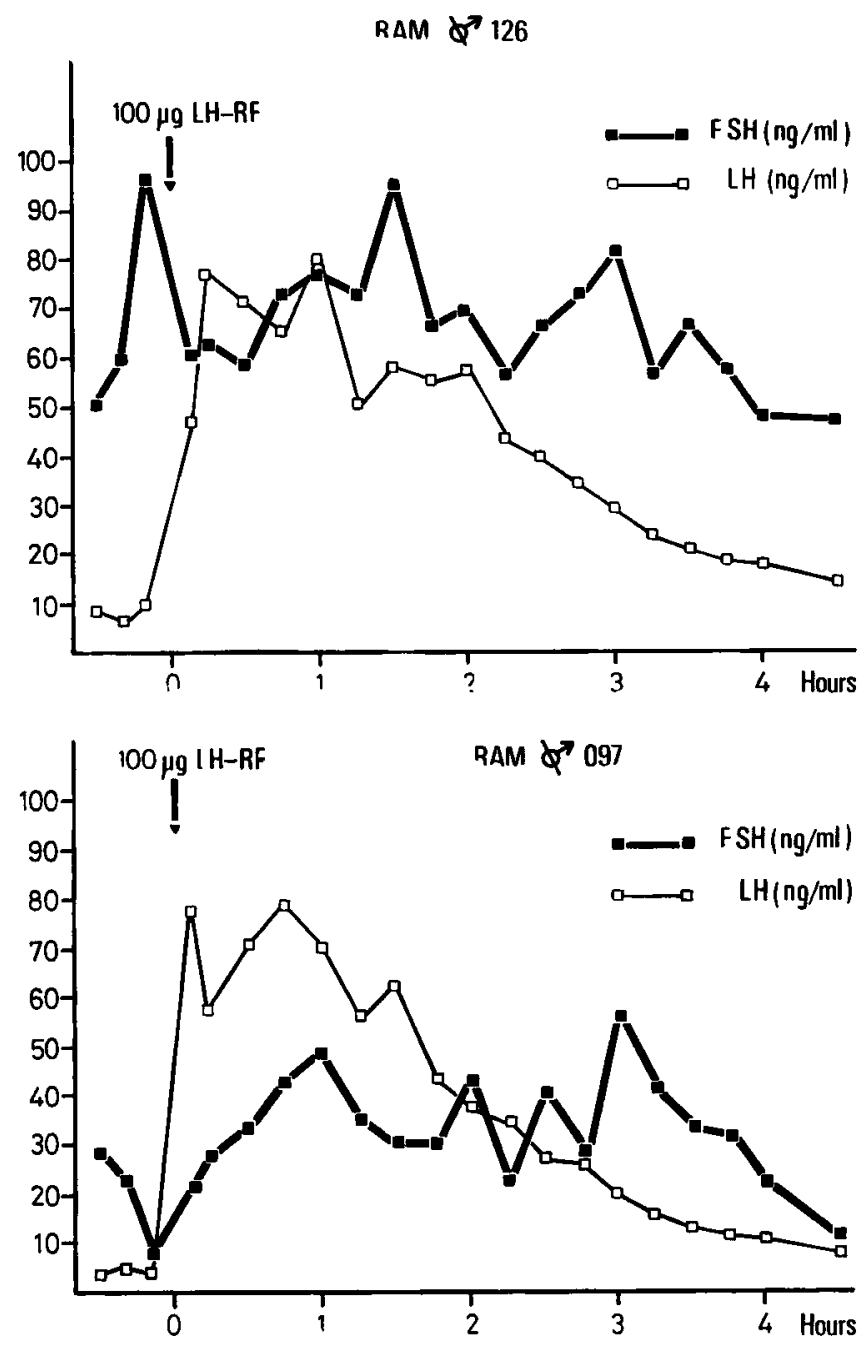

FIC. 2. - Effect of intravenous injection of $100 \mu \mathrm{g} L H-R F$ on FSH and $L H$ releases in the castrated ram

Much more detailed studies were realized in man ; they indicated that intensity of $\mathrm{L}, \mathrm{H}$ response increased with the dose of $\mathrm{LH}-\mathrm{RF}$ given and that maximum plasma $\mathrm{L} H$ level was reached at about $30 \mathrm{mn}$ post-injection (AвE et al., I972; AoNo et al., I973; REBAR et al., I973; KLEY et al., I974; FINK et al., I974; YEN et al., I972a).

Interesting findings resulted from a comparison of LH-RF administration routes. It appeared that intramuscular injections were about as effective as intravenous ones (KEL,LER and GERBER, I973), and that the effectiveness of the latter 
did not differ from sub-cutaneous injections (ARIMURA et al., I973). Sublingual or intranasal routes were proven effective, although less efficient, than the three abovementioned ones (FINk et al., I974; KELLER and GERBER, I973).

Generally, a more discrete FSH increase took place simultaneously with $\mathrm{LH}_{\mathrm{H}}$ increase after LH-RF administration, but a greater time lapse was frequently needed to reach the peak than in the case of $\mathrm{LH}$ (about $60 \mathrm{mn}$ vs $30 \mathrm{mn}$ ) (AONO et al., I972 ; ABE et al., I972 ; YEN et al., I972 b; REBAR et al., I973). Very slow and continuous FSH level increase has been shown following LH-RF infusion in man (BREMNER et al., I974).

Repeated LH-RF treatments were not effective in maintaining high plasma LH level. For example, in entire rams submitted to seven successive Ioo $\mu \mathrm{g}$ LH-RF injections at $30 \mathrm{mn}$ intervals, plasma $\mathrm{L} H$ rose to a plateau between 90 to $\mathrm{I}_{50} \mathrm{mn}$ after the first injection, but the last two treatments failed to prevent a return to pre-injection level (GALLOWAy et al., I974). Similar findings were shown in different male species such as bull (SCHAMs et al., r974), rat and hamster (SANDOw and BABEJ, I973). Plasma FSH seemed differently affected. Repeated treatment did not induce FSH reduction in cattle (ScHams et al., I974). On the other hand, infusion technique, from the point of view of administration route, was considered to improve FSH release in male rats as compared to injection (ARIMURA, DEBELJUK and Schali, I972 $a$; DEBELJUK et al., I973a).

\section{II. - IH-RF EFFECT IN CASTRATED MALES. STEROID INFLUENCE,}

When purified porcine L.H-RF was given to wethers, much stronger $\mathbf{L H}$ response was elicited (about ten times the entire male $\mathrm{LH}$ response), and the effect was dose-related (REEves et al., I970). Peak value was reached very quickly in about ten minutes. Similar results were obtained by Galioway and PeLLETIER (I975) in Ile-de-France and Préalpes $d u$ Sud breeds, castrated six months before receiving synthetic LH-RF (fig. $2 b$ ). However, the time required to reach peak level after LH-RF differed between breeds $(29 \pm 5$ vs II $\pm 2 \mathrm{mn}(\mathrm{P}<0.0 \mathrm{I})$ for the Ile-de-France and Préalpes $d u S u d$, respectively). The significance of this fact remains to be determined. Very frequently a biphasic pattern in LH release was observed, as in figure I $b$, a second peak occurring approximately $\mathrm{r}$ hour after the first one. It is suggested that in castrated animals where both $\mathrm{L}_{4} \mathrm{H}$ synthesis and release are high, newly synthesized L,H could reinforce the intensity of L/H secretion from the realizable $\mathrm{LH}$ pool.

$\mathrm{LH}$ response to $\mathrm{LH}-\mathrm{RF}$ was also higher in castrated bulls than in entire ones, as far as peak level was concerned. However, the area under the L,H curve did not differ significantly (MongkonPunya et al., I974). Similarly, increased LH release was found in castrated rats treated with LH-RF (WATSON et al., I97I ; Roor et al., I973; DEBELJUK et $a l .$, I973 b) or in hypogonadic human males (KASTIN et al., I972 ; RoTH et al., I972) ; release, in each case, was compared to that in entire males.

Although extra FSH release after LH-RF has been observed in humans and rats, no clear incidence of castration status has been mentioned (WATson et al., I97I ; Root et al., I973). 
Finally, castrated male $\mathrm{LH}$ response to $\mathrm{LH}-\mathrm{FR}$ differs, at least in rams, from entire male response in two ways. First, the magnitude of the peak level is much greater in the former; second, delay in reaching the peak is markedly shorter (see fig. I $a$ and $\mathrm{I} b$ ). It may be that the quantitatively greater gonadotropic response to LH-RF is due to higher hormonal pituitary content. To check this point, LH-RF was given to rams which were castrated three hours beforehand under local anesthesia. Figure 3 indicates that the $\mathrm{LH}$ response to $\mathrm{LH}-\mathrm{RF}$ did not differ quantita-

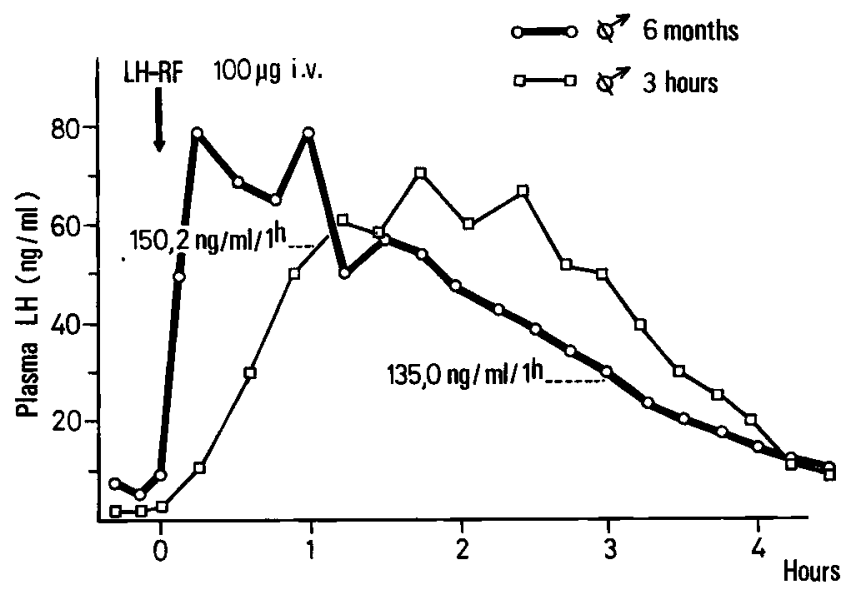

FIG. 3. - Effect of intravenous injection of $100 \mu \mathrm{g}$ LH-RF in short-term (3 hours) or long-term (6 months) castrated rams

(from Galloway and Pelletier, 1975)

tively in short-term and long-term castrated rams, although the delay in reaching peak level was different (GAILOWAY and PEL,ETIER, I975). This indicates that enhanced response to $\mathrm{LH}-\mathrm{RF}$ in castrated animals is not due to higher pituitary content, even if it is presumably involved in long-term castrates ; it strongly suggests that the circulating testosterone level ensures a potent inhibitory action on the LH-RF-LH system at pituitary level. Indeed, it requires several months after castration before pituitary gonadotropin content increases in rams (PELLETIER, I968), but three hours are probably sufficient for testosterone, the main gonadal circulating steroid in this species (ATTAL, I970), to decrease to a very low level since half-life is short (in the minute range) (TERQur et al., I974). Such a striking difference between intact and short-term castrated bulls was not observed by MoNGKONPUNYA et al. (I974), when LH-RF was given seven days post-castration. The dose used $(40 \mu \mathrm{g})$ was perhaps too low to fully reveal the difference in sensitivity to LH-RF between entire animals and castrated ones. PoMERANTz et al. (I974) found that $\mathrm{LH}$ response to $\mathrm{LH}-\mathrm{RF}$ was greater in castrated than in entire pigs, but that the slopes of the computed log-dose-response curves were not significantly different ( $b=3.22$ for castrates, and $b=2.20$ for intact pigs). Consequently, the authors rejected the hypothesis of increased pituitary responsiveness to LH-RF in castrates ; they thought that the difference in response to $\mathrm{LH}$-RF could be due to initial pituitary content in castrated and intact animals. However, the three 
doses used could be insufficient to accurately describe the $\mathrm{LH}$ response curve to LH-RF, and further experiments on short-term castrated animals appear necessary before definitive conclusions can be drawn.

Another approach in studying the feedback effect of gonadal steroids in the hypothalamo-hypophyseal system was to inject testosterone or testosterone propionate into castrated animals.

Acute or chronic treatments produced different results, the quantity of testosterone administered greatly influencing $\mathrm{LH}$ response to LH-RF.

In long-term castrated rams, relatively large doses of testosterone were needed to modify plasma LH (PELLETIER, r970), and this effect was shown to be modulated by light photoperiod (Pelletier, I97I; Peiletier and OrTavant, I975). Occasionally in June, $200 \mathrm{mg}$ testosterone propionate were insufficient to modify plasma LH (PELLETIER, unpublished results) and a standard dose of $600 \mathrm{mg}$ testosterone or testosterone propionate was adopted. This intramuscular injection induced a

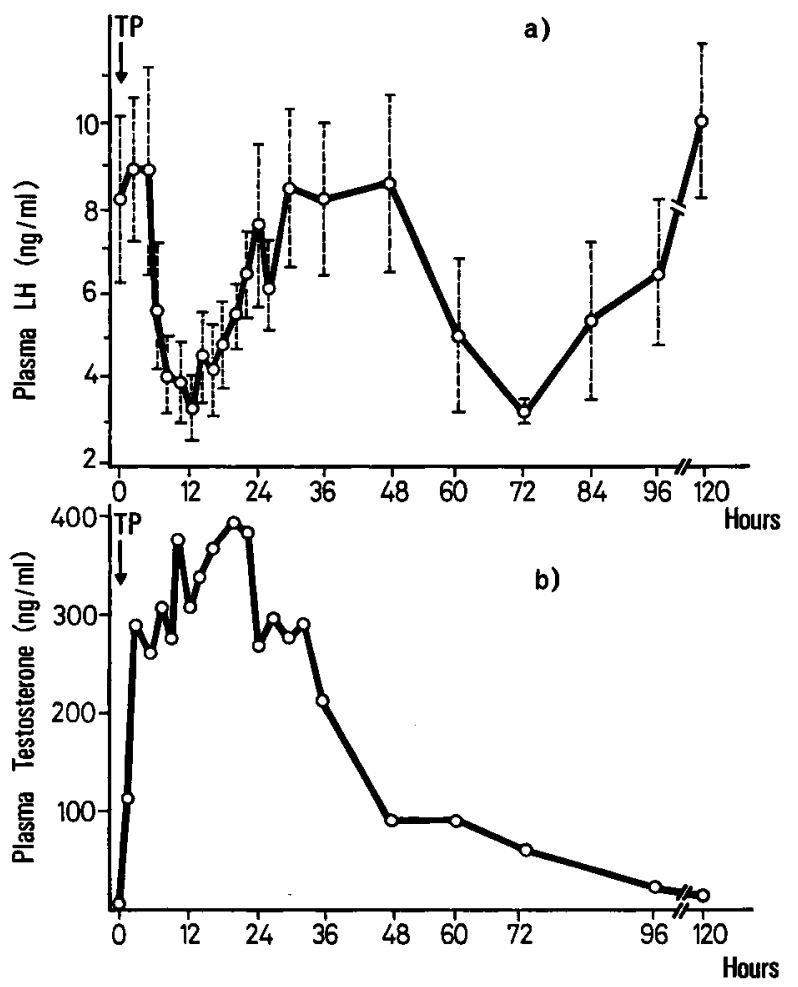

FIG. 4. - Influences of intramuscular injection of $600 \mathrm{mg}$ testosterone propionate in castrated rams on :

a) LH release into the blood

b) plasma testosterone level

(From Garnier et al.)

biphasic decrease in plasma $\mathrm{LH}$ which was maximum $\mathrm{I} 2$ and 72 hours after injection (fig. $4 a$ ), these two decreases being separated by a return to the pre-injection level (Pelletier and Ortavant, I972; Peilietiek, I974 $a$ ). Compared to the LH res- 
ponse to LH-RF observed in castrated control animals, the response was quantitatively similar in rams receiving $100 \mu \mathrm{g} L \mathrm{H}-\mathrm{RF}, \mathrm{I} 2,72$ and $\mathrm{I} 20$ hours after the testosterone propionate injection. Conversely, $\mathrm{LH}$ response was significantly reduced in rams receiving L,H-RF 6 hours after the steroid injection (96.0 \pm 5.46 vs I50.3 $22.95 \mathrm{ng} / \mathrm{ml} / \mathrm{I} \mathrm{h}, \mathrm{P}<0.00 \mathrm{I} ;$ Peiletier, I974 $a$ ) at a time when plasma testosterone was close to maximum value (fig. 4 b) (GARnier et al.). Finally, a decrease in $\mathrm{LH}$ response to $\mathrm{LH}-\mathrm{RF}$, assumed bo be a decrease in the pituitary responsiveness to $\mathrm{L} H-\mathrm{RF}$ due to high levels of circulating testosterone, was observed only 6 hours after the steroid injection. The very high circulating testosterone levels needed to modify the pituitary response to $\mathrm{L}_{\mathbf{H}} \mathrm{H}-\mathrm{RF}$ suggests that in long-term castrated animals, a loss of pituitary sensitivity to testosterone has occurred. However, another possibility is that other steroids, such as oestradiol, participate in the feedback mechanism (see below). Return to pre-injection LH level occurred while plasma testosterone levels were still high ; this suggests that when pituitary is exposed to too long high testosterone levels, it escapes from the inhibitory action of testosterone, as if some preservative mechanism acted as a switch (GARNIER et al.). Comparisons of figure $4 a$ and $4 b$ show that this second $\mathrm{LH}$ decrease occurs when plasma testosterone itself has been considerably decreased. From concomitant measurements of plasma and pituitary $\mathrm{L}_{1} \mathrm{H}$ and hypothalamic L.H-RF activity, it was shown that this second phase of low $\mathrm{LH}$ release resulted from a decrease in LH-RF synthesis (PELLETIER, I970 b). Thus, acute strong treatment with testosterone induces a biphasic decrease in plasma LH in castrated rams. This is due to two distinct mechanisms of different latency. Such results have not been accurately observed in entire rams or even in other species where testosterone-L,H-LH-RF interrelationships have been studied less extensively. Hopkinson et al. (I974) just mentioned that testosterone propionate decreased $\mathrm{LH}$ response to $\mathrm{LH}-\mathrm{RF}$ in rams.

In intact male dogs, $25 \mathrm{mg}$ testosterone or $2.5 \mathrm{mg}$ dihydrotestosterone were not able to decrease $\mathrm{L}_{4} \mathrm{H}$ response to LH-RF (JonES and BoYNS, I974). However, the steroid was injected intramuscularly just prior to LH-RF administration. DEBELJUK et al. (I972 $a$, I974) found that both testosterone and dihydrotestosterone, given 48 hours before, depressed, LH-RF action on LH release in castrated male rats. As in the case of intact male rats, these steroids did not modify FSH response to LH-RF.

LH-RF has not been given to rams pre-treated with oestradiol, but it is known that this steroid is highly efficient in decreasing plasma $\mathrm{LH}_{\mathrm{H}}$ (BoLT, I97I), even in long-term castrated males (PEILETIER, unpublished results). For example, Ioo $\mu g$ oestradiol benzoate induced $50 \mathrm{p}$. roo $\mathrm{LH}$ decrease during the first I2 hours posttreatment, as it did in castrated females. Thus, oestradiol would be about 6 ooo times more potent than testosterone in decreasing LH release. Similarly, I7 $\beta$-oestradiol or oestradiol benzoate decreased LH response to LH-RF in intact dogs (JONES and Boyns, I974) and rats castrated one day before (DEBELJUK et al., I973 b). The combination of testosterone propionate plus oestradiol benzoate strongly inhibited the effect of LH-RF on LH release (DEBELJUK et al., 1972).

VAN DIETEN et al. (I974) have shown that oestradiol first inhibited LH response to LH-RF in male rats, but that later, increased response was observed. A similar increase in LH-RF sensitivity, following a period of decreased sensitivity, was also shown in testosterone propionate-treated rams (PEL,LETIER, 1974a). 
The suggestion that other gonadal hormones may be involved in regulating $\mathrm{L}, \mathrm{H}$ secretion (GAY and DEVER, I97I) is supported by the fact that oestrogens are normally secreted by the testis in human, simian and dog (KELCH et al., I972). If this is true in ram, it would provide a satisfactory hypothesis to explain why so large a quantity of testosterone is needed to decrease plasma $\mathrm{LH}$ level. However, no change of testosterone into oestrogens has been observed at peripheral level in testosterone propionate-treated ram (such a change can occur at hypothalamic or pituitary sites), and the hypothesis of progressive loss of pituitary sensitivity to steroids must not be discarded since insensitivity increases with time after castration (PELLETIER, I970 a). This does not agree with the statement that testosterone (and related compounds) absence from the blood, is the only factor responsible for hypersensitivity to LH-RF in castration status.

To summarize, it appears that, when sufficient steroid dose is given at an adequate time before LH-RF administration, a decrease in pituitary responsiveness to LH-RF occurs, at least as far as $\mathrm{LH}$ is concerned. But, it is apparent from figure I $d$, that this decreased response is not accompanied by an increase in the time required to reach peak $\mathrm{LH}$ value after $\mathrm{L}, \mathrm{H}-\mathrm{RF}$ administration.

Chronic testosterone propionate treatment of long-term castrated rams (seven successive injections of $200 \mathrm{mg}$ testosterone propionate 48 hours apart) gave a clearly different pattern of $\mathrm{L}, \mathrm{H}$ response to L,H-RF than that observed in acute experiments. $\mathrm{LH}$ response to $\mathrm{LH}-\mathrm{RF}$ (given 24 hours after the last steroid injection) was quantitatively similar to that observed in castrated control rams, in spite of low LH level at the time of LH-RF injection (I55.I \pm 23.0 vs I47.2 $\pm 2.9 \mathrm{ng} / \mathrm{ml} / \mathbf{I} \mathrm{h}$; GAILOWAY and PELLETIER, I975). However, the time needed to reach peak level was about two hours (fig. I c), which is very close to that observed in intact LH-RF-treated rams. Thus, in these chronic-treated animals, an increase in the time needed to reach peak level was obtained without any change in response intensity. This result is complementary to that found following acute treatment (compare fig. I $b$ and $\mathrm{I} d$ ) and suggests that in ram, testosterone could act in two different, relatively independent, ways at pituitary level :

a) by inhibiting the magnitude of pituitary response to LH-RF,

b) by delaying $\mathrm{LH}$ response to LH-RF.

We have previously seen that quantitative inhibitory action disappeared first, quickly after castration (GALLOWAY and PELLETIER, 1975).

After a chronic testosterone treatment for six days in castrated cattle, MoNGKONPUNYA et al. (I974) concluded from LH-RF studies that testosterone is not the gonadal factor modifying pituitary responsiveness to LH-RF in bulls. While this assumption is plausible (see above), it cannot be considered conclusive since the actual testosterone treatment ( $60 \mathrm{mg} / \mathrm{day}$ ) might have been insufficient in castrated cattle and the influence of the time "last steroid injection-LH-RF administration", which is fundamental to understanding the very effect of LH-RF (PELLETIER, I974a), has not been studied.

Finally, a natural variation in L,H-RF sensitivity, at least in sheep, summarized the changes which occurred when castrated adult rams were compared to chronic testosterone-treated rams : the lamb from birth to puberty. Figure 5 shows that L,H-RF, when given at 60 days of age or earlier, induced $\mathrm{LH}_{\mathrm{H}}$ response presenting 
a peak level as early as ro-25 $\mathrm{mn}$ post-injection. This time delay, a castration-type response, increased with age to reach an adult pattern at I40 days of age; peak level was reached in about 2 hours (GAlioway and PELLETIER, I974). When two months old, lambs have testosterone in the blood (ATTAL, I970) and respond to

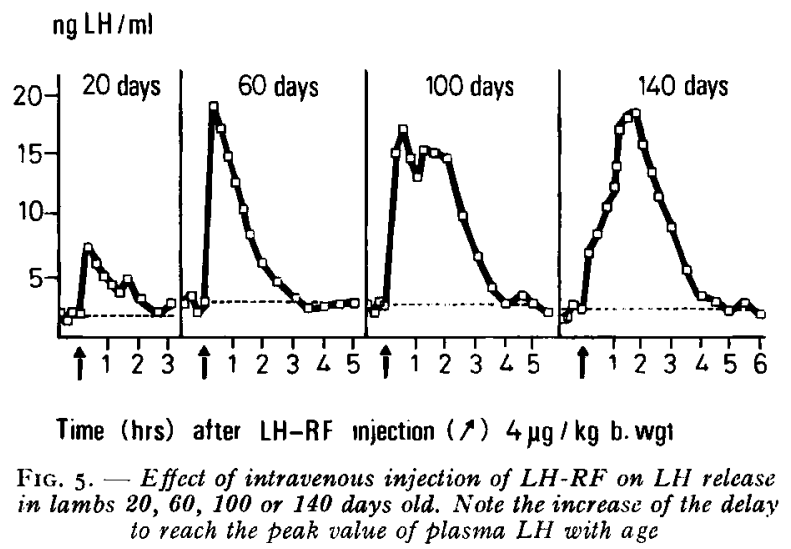

(from Galloway and Pelletier, 1974)

castration by LH increase (FOS'TER et al., r972), but it would seem that maturity is not achieved, as far as hypothalamo-hypophyseal sensitivity to testosterone is concerned. This is supported by parallel increases in plasma $\mathrm{LH}$ and testosterone from birth to week Io of life (COTTA et al., I975).

\section{III. -- LH-RF EFFECT ON FEMAI,E LH AND FSH RELEASES}

As in the male, the earliest studies conducted in ewe indicated that crude ovine hypothalamic extract injections induced immediates $\mathrm{LH}$ release into the blood, the maximum value reaching about 25 times the pre-injection level in IO-I5 mn (NISWENDER, I969; GAY et al., I970). The intensity of response appeared dose-related. Comparable results were obtained when purified porcine hypothalamic extracts were used (REEVES et al., I970), although no dose-response curve was found, presumably because doses injected were too low. Later, the availability of synthetic LH-RF encouraged great progress in this field.

Administration of synthetic LH-RF to anestrous ewes induced an immediate increase in plasma FSH and $\mathrm{LH}$ levels, and the magnitude of response was related to LH-RF dose ranging from 0.2 to about $500 \mu \mathrm{g}$ (RIPPEL et al., I974; Symons et al., 1974). Peak values were reached later (I00-150 $\mathrm{mn}$ ) when the highest doses were given, but these did not prolong the high-level period, and at about 6 hours post-injection, plasma concentrations were close to baseline. No biphasic pattern in LH release, such as those pointed out by ARIMURA et al. (I972), have been mentioned by others.

LH and FSH release patterns are similar. However, while the $\mathrm{LH}$ peak value may represent Ioo times the pre-injection level, that of FSH is more discrete and 
is only five times greater than the baseline (Symons et al., I974). It should be noted that the injection route (intravenous, intramuscular or subcutaneous) seems of little importance in response intensity or the time needed to reach the peak.

When two LH-RF injections were given, the effect was related to the interval between them. If the interval was only 3 hours, $\mathrm{FSH}$ and $\mathrm{LH}$ responses were rather similar after the two injections, but if it was 24 hours, the LH response was considerably lower (REEves et al., I972 ; Symons et al., I974). A third injection 24 hours later was followed by further decreased response.

Similarly, anestrous ewes infused for a period of 24 hours with LH-RF presented an increase in plasma LH level which was maximum 3 hours after the beginning of infusion, and then declined (ChAKRABORTy et al., I974). However, if the infusion time was only 3 hours, no decline in plasma gonadotropins was apparent and plasma FSH and I,H patterns were parallel (JonAs et al., I973). As in the male, these results suggest a change in the pituitary responsiveness to LH-RF due to steroids.

The effects of LH-RF administered to heifers are similar to those observed in ewe, both for the relative increases of plasma FSH and LH levels and the time needed to reach the peak (Zolman et al., I973; KaLtenbach et al., I974 ; Schams et al., I974). Repeated treatments with LH-RF are followed by a decrease in L.H response, but, rather curiously, that of FSH does not (Schams et al., I974).

From the limited data available, it appears that in pig, $\mathrm{L}_{1} \mathrm{H}$ response to $25 \mu \mathrm{g}$ LH-RF was immediate but low (CHAKRABORTY et al., I973), a fact which may be related to weak preovulatory surge (NISWENDER et al., I970) rather than to the relatively small dose used since increasing the amount of $\mathrm{LH}$ - $\mathrm{RF}$ administered up to I $\mathrm{mg}$ did not improve $\mathrm{LH}$ release (BAKER et al., I973). The LH response to LH-RF decreased during a chronic treatment at 6 hour intervals, but was not abolished (Chakraborty et al., I973).

\section{IV. - VARIATIONS IN PITUITARY RESPONSIVENESS TO LH-RF IN} THE FEMALE. STEROID INFLUENCE

In I964, BogDANOvE suggested that variation of $\mathrm{LH}$ release into the blood could be the result of a change of pituitary responsiveness to hypothalamic hormone. Six years later, REEves et al. (I97 I b) showed that LH response to purified porcine hypothalamus injected into ewes varied during the estrous cycle and was maximum around the period of estrus. Furthermore, injecting oestradiol benzoate to anestrous ewes greatly improved $\mathrm{LH}$ reponse to $\mathrm{L} H-\mathrm{RF}$, an effect again attributed to an incrase in pituitary responsiveness to LH-RF (REEVEs et al., I97I $b$ ). After these pioneer works, attention was focused, in many species, on intensity of LH release after L.H-RF was given at different stages of the estrous cycle or in females pretreated with steroids, oestrogens or progesterone.

Conflicting results were obtained when LH-RF was given at different stages of ewe estrous cycle. Contrary to REEves et al. (I970), Foster and Crighton (I974), Symons et al. (I974) and RIPPEL et al. (I974) did not find a difference in LH release intensity after administration of LH-RF during the estrous cycle, but these authors may not have chosen the most representative moments of great steroid variation. 
On the other hand, for both FSH and $\mathrm{L}_{4} \mathrm{H}$, responses to $\mathrm{LH}-\mathrm{RF}$ werefound to be greater in ewes infused for 4 hours on days $15-17$ than in those infused on days 2-I2 (Hooley et al., I974).

To clear up this problem, we injected Ile-de-France ewes with $25 \mu \mathrm{g}$ of synthetic LH-RF at days 4,8, I 2 or I 6 of the estrous cycle, and determined I $7 \beta$-oestradiol and progesterone plasma levels before LH-RF injection. For each of these four stages of the cycle, I $7^{\beta}$-oestradiol was $2 I, 3 I, I I$ and $3 I \mathrm{pg} / \mathrm{ml}$ (mean for 3 ewes) and progesterone was $0.80,2.40,1.90$ and $0.95 \mathrm{ng} / \mathrm{ml}$. Expressed in percentage of the response observed on day $I 6$, the mean $L H$ response to $L H-R F$ was $39, I 6$ and I3.5 p. Ioo for days 4,8 and I2, respectively. Intensity of $\mathrm{LH}$ response was negatively correlated with plasma progesterone level $(r=-0.7)$, but a better correlation was obtained between oestradiol/progesterone ratio and $\mathrm{LH}$ response to $\mathrm{LH}-\mathrm{RF}$ $(r=+0.97, \mathrm{P}<0.05)$ (THIMONIER et al., I974). Thus, circulating steroids would produce a regulation of $\mathrm{L} / \mathrm{H}-\mathrm{RF}$ effect acting at the pituitary level at any time. Similar conclusions have been drawn in ram where the intensity of $\mathrm{LH}$ release after $\mathrm{L} H-\mathrm{RF}$ was correlated with previous circulating testosterone level (GALIOWAY et al., I974).

Few data are available on other domestic species. Zorman et al. (I974) concluded from LH-RF injections to cyclic heifers that the day of treatment in the cycle ( $I_{5}$ or 20) did not influence $\mathrm{LH}$ response to $\mathrm{LH}-\mathrm{RF}$, although an increase in plasma oestradiol and a decrease in plasma progesterone have been registered at D20. However, a more complete study would be interesting.

On the contrary, greater $L H$ response to $L H-R F$ was observed in cows with cystic follicles than in luteal cows, although no differences in oestradiol plasma levels were shown before injection (KITTOK et al., 1973).

Finally, in spite of contradictory results, the hypothesis of a variation in pituitary response to LH-RF according to the stage of the estrous cycle is the most plausible hypothesis in domestic animals. The maximum response would be obtained at times when plasma oestrogens would be high and progesterone level low. Conversely, when the progesterone level is high (for example, during pregnancy) both FSH and LH responses to LH-RF are reduced (CHAMLEY et al., I974 $a$ and $b$ ). Similar studies in a number of species, such as hamster (ARIMURA et al., I972 b), rat (COOPER et al., I973; AIYER et al., I974) or man (YEN et al., I972 b), add further evidence for changes in pituitary responsiveness during the cycle. However, the relationship between plasma steroid level and LH response to LH-RF needs further research.

The previous conclusion is supported by works involving steroid administration. REEVES et al. (I97I $b$ ) indicated that benzoate oestradiol injection increased $\mathrm{LH}$ response to $\mathrm{LH}-\mathrm{RF}$ in anestrous ewe. Conversely daily injection of $20 \mathrm{mg}$ progesterone for $\mathrm{I} 4$ days or infusion of $500 \mu \mathrm{g}$ progesterone/hr for 76 hours significantly suppressed LH and FSH responses to LH-RF (PANT and WARD, I973; HooLEY et al., 1974). Short progesterone infusion (500 $\mu \mathrm{g} / \mathrm{hr}$ for $24 \mathrm{hrs}$; Cummings et al., I972 a) or pretreatment with pessaries impregnated with $20 \mathrm{mg}$ fluorogestone acetate (9-fluoro II $\alpha$-I 7-dehydroxypregn 4ene, 3-20-dione I7-acetate, Searle Co. ; ChaKRaBorTy et al., I974) did not modify pituitary response to LH-RF in anestrous ewes. Furthermore, a decrease in pituitary responsiveness also occurred when oestradiol and progesterone were given together (DEBELJUK et al., I972 b). 
Increased pituitary responsiveness to LH-RF following oestrogen administration was also shown in female rat (ARIMURA and SCHALLY, I97I) and in woman (JAFFE and KEYE, I974), but more precise studies indicated in both cases that oestrogens had two opposite effects. First, when given a few hours ( 4 to 6 ) before LH-RF, oestrogens decrease L,H response to the latter (LIBERTUN et al., I974; VILCHEZMARTINEZ et al., I974; LEgan et al., I974; ThOMPSON et al., I973). From changes in $\mathrm{FSH} / \mathrm{LH}$ plasma ratio, it would seem that inhibitory effect of oestrogen could affect preferentially the FSH more than the LH release (LIBERTUN et al., I974; KEYE and JAFFE, I974). Second, an amplified effect of LH-RF is observed if the time between oestrogen and LH-RF treatments increases. When it reaches 24 hours, $\mathrm{L}, \mathrm{H}$ response to $\mathrm{LH}-\mathrm{RF}$ increases with the pretreatment dose of oestrogen used (KULKARNI et al., I974). In sheep, similar conclusions can be drawn when one considers plasma $\mathrm{LH}$ patterns in ovariectomized ewes injected with $50 \mathrm{\mu g}$ oestradiol benzoate (PELLETIER and SignORET, I970) : the plasma LH decreased about 80 p. IOO during the first I4 hours post-injection before a "preovulatory " type of surge occurred, and this decline is presumably correlated whith an initial decrease in pituitary responsiveness to LH-RF. In Australian ewes grazing oestrogenic clover, the $\mathrm{L}_{\mathrm{H}} \mathrm{H}$ release-inducing effect of exogenous oestradiol is more or less abolished, but $\mathrm{L}, \mathrm{H}$ response to LH-RF infusion is not (FIndLAY et al., I973). As in sheep, progesterone has been generally accepted as decreasing the LH-RF effect in rat (ARIMURA and Schally, I970), rabbit (HILIARD et al., I97I) or woman (Thompson et al., I973).

To summarize, oestrogens would have a biphasic effect, first inhibitory then facilitative, on gonadotropic response to LH-RF; progesterone itself and high concurrent levels of oestrogen and progesterone would, on the contrary, have an inhibitory effect.

\section{V. - LH-RF EFFECTS IN ANESTROUS EWES AND LACTATING EWES}

LH-RF has not only been considered as a proven tool for fundamental research ; it focused the attention of workers trying ot induce FSH and LH releases in reproductive animals which have intermittent cyclicity during the year. It was also important to clinicians confronting anovulatory disorders in woman (ZARATE et al., I972). If we consider reproductive animals only, sheep is mainly involved since the female cyclicity usually stops for several months, depending on the breed and country.

Preovulatory LH release was initially induced in anestrous ewe with either oestradiol (GoDING et al., I969; RADFORD et al., I970 ; BECK and REEVES, I973) or PMSG (ThIMONIER and CoGNIE, I97I). However, in ewes synchronized with a progestagen, oestradiol tended to reduce fertility (RoBINson et al., I970) and PMSG induced appearance of refractoriness leading to reduced ovulation rate when given too frequently. Thus, LH-RF could be considered as a more convenient inducer of LH release. REEVES $e t$ al. (I972), JoNAS et al. (I974), Symons et al. (r974) induced both $\mathbf{L H}$ and FSH releases with $\mathrm{LH}-\mathrm{RF}$ given to anestrous ewes, and REEvES et al. (I974) indicated that intensity of response did not differ in early, mid or late anestrus. We have confirmed that in ewes synchronized with vaginal sponges impregnated with $40 \mathrm{mg}$ FGA, injected with 600 IU PMSG the day of sponge removal 
and subjected 24 hours later to two intramuscular injections of $200 \mu \mathrm{g} \mathrm{LH}-\mathrm{RF}$ at a four hour interval, intensity of LH release is as great as in ewes during sexual season (PEILETIER, I974 b). However, omission of PMSG injection results in a significant $26 \mathrm{p}$. Ioo decrease in the quantity of $\mathrm{LH}$ released, computed from the area between the actual $L_{H} H$ pattern and the pre-injection level assumed to be constant. Intensity of $\mathrm{LH}$ release was similarly reduced in ewes receiving one $400 \mu \mathrm{g}$ injection of $\mathrm{LH}-\mathrm{RH}$ in place of two $200 \mu \mathrm{g}$ injections with or without PMSG. Our data differ from those of RIPPEI et al. (I974), who found that $\mathrm{LH}$ release in anestrous ewes receiving only Ioo $\mu \mathrm{g}$ LH-RF was as great or even greater than that of cyclic ewes. In the latter case, however, females were not synchronized.

TABLE I

Influence of $L H-R F$ on $L H$ release in dry ewes and in 40 day post partum lactating and-non lactating eues treated during seassnal anoestrus

\begin{tabular}{|c|c|c|c|}
\hline Group & $\mathbf{n}$ & $\begin{array}{c}\text { PMSG-LHRF }\left({ }^{1}\right) \\
\text { Interval } \\
\text { (hours) }\end{array}$ & $\begin{array}{c}\mathrm{LH} \text { release }\left({ }^{2}\right) \\
(\mathrm{ng} / \mathrm{ml} / \mathbf{1 ~ h})\end{array}$ \\
\hline Dry ewe & 6 & 24 & $313 \pm 47.0$ \\
\hline Dry ewe & 6 & 30 & $279 \pm 44.3$ \\
\hline Lactating ewe & 6 & $\because !$ & $169 \pm 30.0$ \\
\hline Lactating ewe & ci & 30 & $177 \pm 47.0$ \\
\hline Non-lactating ewe & 4 & $\underline{-3}$ & $141 \pm 7.9$ \\
\hline
\end{tabular}

(1) All females were synchronized with $40 \mathrm{mg}$ fluorogestone acetate given intravaginally for 6 days and treated immediately after sponge removal with 600 IU (dry ewes) or 750 IU (post-partum ewes) PMGS given intramuscularly and later ( 24 or 30 hours) with intravenous injections of LH-RF (twice $200 \mu \mathrm{g}$ at 4 hour interval).

(2) Total LH release was expressed in $\mathrm{ng} / \mathrm{ml}$ per one hour as if all the $\mathrm{LH}$ release occurred in the interval of one hour only (in part from Pelcetier, 1974 b).

It was more difficult to induce preovulatory $\mathrm{LH}$ release in the post-partum period, namely, when lactating anestrus is superimposed on seasonal anestrus. In these conditions, it has been shown that PMSG or oestradiol LH-induced release was 20 to $30 \mathrm{p}$. IOo less than that observed in similarly treated dry ewes (PELLETIER and THIMONIER, 1973; LEWIS et al., 1974), although the pituitary contents were not found to be different in the two cases (PEI,LETIER and THIMONIER, unpublished results). Attempts to use $\mathrm{LH}-\mathrm{RF}$ as an inducer of $\mathrm{LH}$ release led to similar results when the lactating females were injected between the third and sixth week postpartum (CHAMLEY et al., I973; RIPPEL et al., I974). With our above-mentioned conditions, $\mathrm{LH}$ release after $\mathrm{LH}-\mathrm{RF}$ is about $4^{\circ} \mathrm{p}$. Ioo less in lactating ewes than in dry ewes (table I) (PELLETIER, I974 b). According to JENKIN and HEAP (I974), the lactation itself would not have an effect per se since a similar decrease in the pituitary response to LH-RF was also observed when lambs were removed at birth. Our preliminary data (table I) confirm this assumption. The low circulating levels of 
oestradiol found in lactating females (CogNIE et al., 1974) suggested that a decrease in pituitary responsiveness could be responsible for this reduced response to LH-RF, and it was interesting to see if increasing the dose of $\mathrm{L}, \mathrm{H}-\mathrm{RF}$ would overcome this lack of sensitivity. During the period of deep anestrus, March, dry ewes or lactating females on the 28 th day post-partum were first given a synchronization treatment with vaginal sponges impregnated with progestogen (30 mg FGA for 12 days) and a PMSG intramuscular injection (400 IU) at the time of sponge removal. Dry ewes and one group of lactating females then received two injections of $200 \mu \mathrm{g} \mathrm{LH}-\mathrm{RF}$ at four-hour intervals 24 hours later. Two other groups of lactating ewes similarly received two injections of 400 and $600 \mu \mathrm{g} L \mathrm{H}-\mathrm{RF}$, respectively. Representative $\mathrm{LH}$ patterns for each of the four groups are given in figure 6 . The mean $L H$ releases,

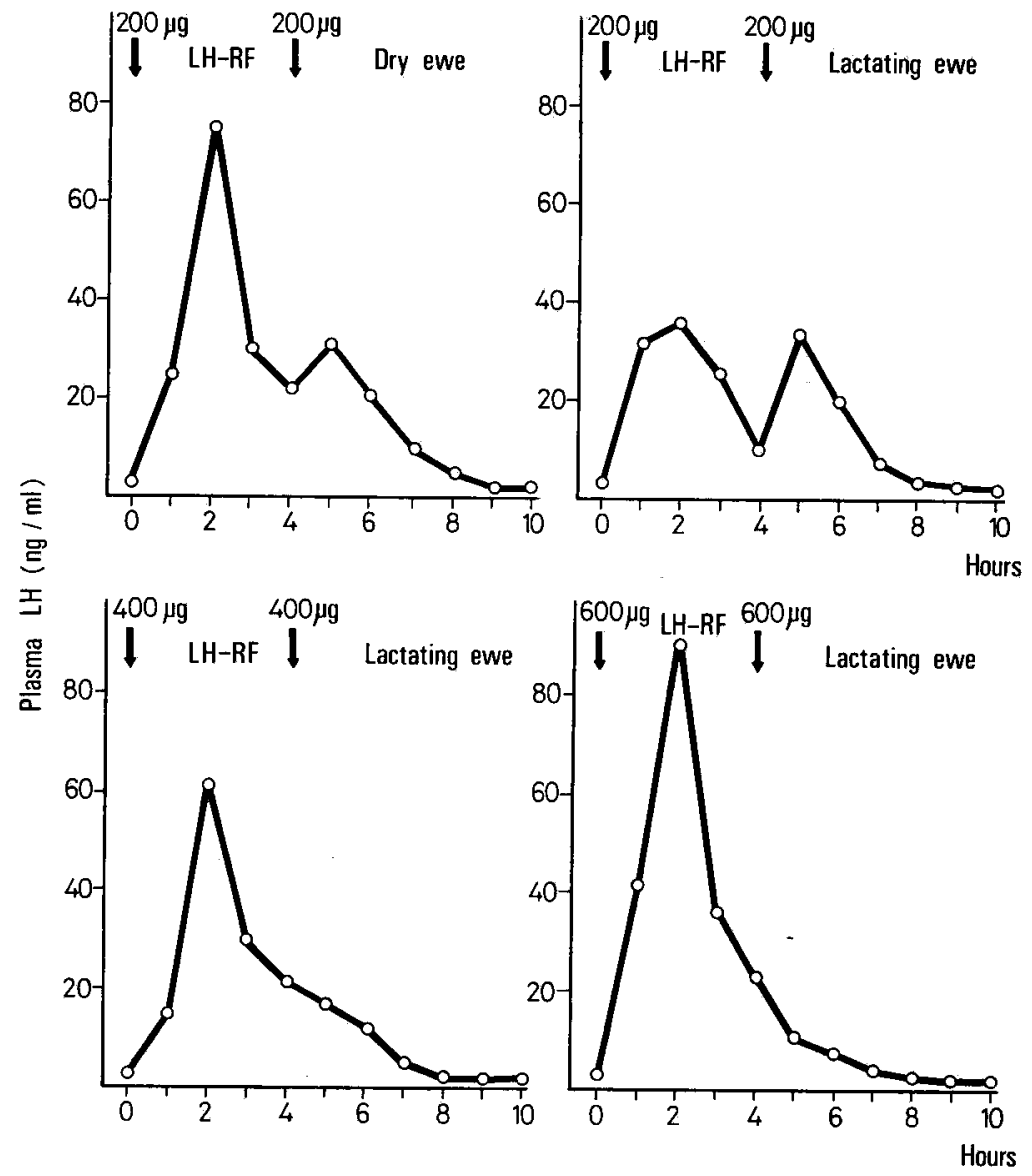

Fig. 6. - Influence of doses of LH-RF on $L H$ release in lactating ewes (40 d. post-partum) in comparison with anoestrous dry ewes

computed from the area under the curve, were $66.4,73.7$ and Ioo p. Ioo of that observed in dry ewes in the $2 \times 200,2 \times 400,2 \times 600 \mu \mathrm{g}$ LH-RF-treated groups, respectively. Further, as the LH-RF dose increased, so did LH response to the first 
injection, but the response to the second injection was progressively abolished. This suggest that pituitary stores of releaseable $\mathrm{L}_{\mathrm{H}}$ were almost completely depleted and that new $\mathrm{L}, \mathrm{H}$ was resynthesized at slow rates in these conditions. From a practical point of view, massive unique LH-RF injection would be better for the induction of $\mathrm{LH}_{\mathrm{H}}$ release in lactating ewes during the seasonal anestrous period as compared to dry ewes where two injections were fund convenient (REEVES et al., I972; SyMONS et al., 1974).

RIPPEL et al. (1974) suggested that decreased pituitary release during lactation was the main factor in infertility. Our feeling is that the hypothalamo-hypophyseal system and genital tract are both involved since ovulation rate and fertility did not appear correlated to intensity of the $\mathrm{LH}$ release (THIMONIER and PELIETIER, I972; LAND et al., I973). However, LH release comparable to preovulatory LH surge of the cyclic ewe is needed in synchronized lactating ewes in order to determine other sources of infertility.

Two other critical points remain open to question. First, in spite of the report of Moss and McCANN (I973), showing that estrus behavior could be induced with LH-RF in female rats, no estrus or irregular onset of estrus behavior was shown in LH-RF-treated ewes (Symons et al., I974; SEGERSON et al., 1974, and our personal observations). However, if $\mathrm{LH}-\mathrm{RF}$, given at an inapropriate time before estrus in cyclic ewe can induce premature ovulation and thus reduce normal fertility (SEGERson $e t$ al., I974), the incidence of estrus failure per se has not been evaluated. Similarly, the lack of estrus could not be relevant to fertility in lactating LH-RF-treated ewes since preovulatory L,H releases are perfectly synchronized and theoretically authorize artificial insemination at an exact time just before ovulation. A clear picture of the relationship between the presence of estrus and fertility is highly needed. Second, the relationship between LH-RF-induced LH release and ovulation has to be considered both in the light of incidence of ovulation and quality of ovulation. If anestrous ewes, treated with LH-RF given by perfusion (CHAkRABORTY et al., I974) or with low acute injection (25 or IOo $\mu \mathrm{g}$ once; RIPPEL et al., I974), did not ovulate, females treated with our progesterone-PMSG-LRF (see above) ovulated readily ; the ovulation rate was close to that observed in similarly treated dry ewes (PELLETIER, I974 b). The quality of the ovulating process is a more difficult point. On one hand, the LH release-ovulation interval, assumed to be constant (CuMMING et al., $1972 b$ ), could differ by 24 hours in PMSG-superovulated lactating females and in the same animal, ovulations could occur at 30 hour intervals (COGNIE and PELLETIER, in preparation). It si highly questionable whether LH-RF will improve the staggered ovulations. On the other hand, LH-RF induces $L H$ and FSH releases but these releases may not, on the whole, represent qualitatively all the " ovulating " release if : a) there is a FSH-RF different from LH-RF, $b$ ) other pituitary hormones are involved in ovulation.

\section{CONCLUSION}

In the last few years, LH-RF has been extensively used, and this paper reviews the large number of results achieved. However, new questions arise and areas of doubt appear. For example why do crude or purified hypothalamic extracts induce 
immediate $\mathrm{LH}$ response in intact rams in the nanogram range, while maximum $\mathrm{LH}$ response to synthetic $\mathrm{LH}-\mathrm{RF}$ is delayed about two hours and that micrograms are needed ? Furthermore, discrete and frequently erratic FSH responses are observed following LH-RFad ministration; afterwards, definite conclusions cannot be drawn from the results positively identifying FSH-RF and LH-RF. Another disquieting point is the frequent absence of systematic study of the delay effect between steroid and LH-RF administration when there may be a change in pituitary responsiveness to LH-RF. More detailed studies need to be done on all these points.

From a practical point of view, the use of LH-RF as an inducer of LH release in anestrous ewe must be completed with other hormonal treatments since the status of the genital tract in post-parturient females surely affects fertility. Presumably, a great deal of research will be necessary before such a " cocktail " works with success.

Scientists must re-new their efforts before the effect of synthetic LH-RF availability can teally be assessed, especially in domestic animals.

Symposium Gn-RH, Tours, 25 mars 1975.

\title{
ACKNOWLEDGEMENTS
}

The work on LH-RF effect on LH release in lactating ewes was supported by the Institut National de la Santé et de la Recherche Médicale (Grant No 74-4-453-35).

\section{RÉSUMÉ}

\section{INFLUENCE DU LH-RF SUR LA LIBÉRATION DE LH ET DE FSH CHEZ LES ANIMAUX DOMESTIQUES}

\begin{abstract}
L'injection intraveineuse de LH-RF à des béliers intacts provoque une libération de LH dans le sang qui est fonction de la dose ; aucune relation n'est observée dans le cas de FSH. Le délai entre l'injection de $100 \mu \mathrm{g}$ de LH-RF synthétique est long, de l'ordre de 2 heures, et le niveau maximum atteint est d'environ $10 \mathrm{ng} / \mathrm{ml}$ de $\mathrm{LH}$. Inversement lorsque le $\mathrm{LH}-\mathrm{RF}$ est injecté à des béliers castrés le délai pour atteindre le pic est court (ro-20 $\mathrm{mn}$ ) et la valeur du pic est beaucoup plus élevée que chez le bélier intact $(70-80 \mathrm{ng} / \mathrm{ml})$. Un tel effet est observé dès 3 heures après la castration. Chez les béliers castrés, une injection unique de $600 \mathrm{mg}$ de propionate de testostérone effectuée 6 heures avant celle du LH-RF diminue le pic de LH de l'ordre de $40 \mathrm{p}$. Ioo sans modifier le temps nécessaire pour atteindre le pic. D'autre part, un traitement chronique par le propionate de testostérone retarde le moment du pic par rapport à l'injection de LH-RF sans modifier l'intensité de la décharge. Il semble donc que la testostérone agisse selon deux voies différentes :
\end{abstract}

a) en diminuant la réponse de $\mathrm{LH}$ au LH-RF;

b) en retardant le moment du pic $\mathbf{L H}$.

Chez l'Agneau mâle, l'injection de LH-RF induit une décharge de LH variable selon l'âge considéré. A 20-6o jours d'âge, le LH-RF induit une libération de LH immédiate comme chez le bélier castré, puis à des âges plus avancés, on observe une augmentation du délai entre l'injection de LH-RF et le pic de LH. A I 40 jours, ce délai est comparable à celui observé chez l'adulte. Ces résultats suggèrent que la maturité du système hypothalamo-hypophysaire n'est achevée qu'à la puberté.

Chez la Brebis, l'intensité de la libération de LH après injection intraveineuse de LH-RF varie au cours du cycle œstrien et est corrélée avec le rapport osstradiol-I $7 \beta /$ progestérone plasma- 
tiques. Le maximum de libération de LH est obtenu au jour $\mathrm{I} 6$ du cycle (Ioo p. 10o) et le minimum au jour I 2 (13.5 p. 10o). La libération de LH après LH-RF varie aussi en fonction de l'état physiologique : chez la brebis sèche la décharge de $\mathrm{LH}$ induite est supérieure d'environ $4^{\circ} \mathrm{p}$. Ioo à celle observée chez la brebis allaitante ou tarie après parturition.

Ces résultats sont discutés en parallèle avec ceux obtenus chez les autres espèces.

\section{RÉFÉRENCES BIBL,IOGRAPHIQUES}

Abe N., Nagata N., Saito S., Tanaka K., Kaneko T., Shimizu N., Yanalhara N., I972. Effects of synthetic luteinizing hormone releasing-hormone on plasma levels of luteinizing hormone and follicle stimulating hormone in man. Endocr. Jap., 19, 77-84.

Aiyer M. S., Fink G., Greig F,, I974. Changes in the sensitivity of the pituitary gland to luteinizing hormone-releasing factor during the oestrous cycle of the rat, $J$. Endocr., 60, 47-64.

Amoss M. S., Guillemin R., I969. Elevation of plasma LH concentrations induced by LH-releasingfactor as measured by radioimmunoassay in the sheep. Endocrinology, 84, 15I7-1520.

Aono T., Minagawa J., Kawamura K., Terakawa N., Tanizawa O., Kurachi K., I972. Gonadotropin reserve function test by administration of synthetic LH releasing hormone. Folia endocr. Jap., 48, 578-587.

Arimura A., Schally A. V., 1970. Progesterone suppression of LH-Releasing hormone induced stimulation of LH release in rats. Endocrinology, 87, 653-657.

Arimura A., Schally A. V., I971. Augmentation of pituitary responsiveness to LH-Releasing Hormone (LH-RH) by oestrogen. Proc. Soc. exp. Biol. Med., 136, 290-293.

Arimura A., Debeljuk L., Schally A. V., 1973. LH release by LH-releasing hormone in golden hamsters at various stages of oestrous cycle. Proc. Soc. exp. Biol. Med., 140, 609-6r2.

Arimura A., Debeljuk I., Schally A. V., 1972. Stimulation of FSH release in vivo by prolonged infusion of synthetic LH-RH. Endocrinology, 91, 529-532.

Arimura. A., Debeljuk L., Matsuo H., Schally A. V., 1972. Release of LH by synthetic LHreleasing hormone in the ewe and ram. Proc. Soc. exp. Biol. Med., 139, 85 I-854.

Arimura A., Saito M., Kumasaka T., Sato H., Koyama T., Nishi N., Kastin A. J., Schally A. V., I973. Comparison of the effects of subcutaneous and intravenous injection of synthetic LHreleasing hormone LH-RF on serum LH and FSH levels in men. J. Clin. Endocr. Metab., 36, 385-388.

AtтAL J., 1970. Mesure des cestrogènes et des androgènes testiculaires et plasmatiques dans l'espèce ovine par des microméthodes de chromatographie en phase gazeuze: influence de l'áge, de la saison et du cycle diurne. These Doc. Sci. University of Paris, $143 \mathrm{p}$.

BAKER R. D., Downey B. R., BRINKLEY H. J., 1973. Induction of ovulation in pigs with gonadotrophin releasing hormone. J. Anim. Sci., 37, I376-1379.

Beck T. W., ReEves J. J., I973. Serum luteinizing-hormone (LH) in ewes treated with various dosages of $17 \beta$-estradiol at three stages of the anestrous season. J. Anim. Sci., 36, 566-57o.

BogDANOVE E. M., I964. The role of the brain in the regulation of pituitary gonadotropin secretion. Vitam. Horm., 22, 206-260.

BoLT D. J., 1971. Changes in the concentration of luteinizing hormone in plasma of rams following administration of oestradiol, progesterone or testosterone. J. Reprod. Fert., 24, 435-438.

Bremner W. J, Paulsen C. A., I974. Two pools of luteinizing hormones in the human pituitary : evidence from constant administration of luteinizing hormone-releasing hormone. J. Clin. Endocr. Metab., 39, 8II-815.

Chakraborty P. K., Reeves J. J., Arimura A., Schally A. V., 1973. Serum lH levels in prepubertal female pigs chronically treated with synthetic luteinizing hormone-releasing hormone/Folliclestimulating hormone-releasing hormone. Endocrinology, 92, 55-61.

Chakraborty P. K., Adams T. E., Tarnavswy G. K., Reeves J. J., I974. Serum and pituitary LH concentration in ewes infused with LH-RH/FSH-RH. J. anim. Sci., 39, II50-II57.

Chamley W. A., Findlay J. K., Cumming I. A., Buckmaster J. M., Goding J. R., 1974a. Effect of pregnancy on the LH response to synthetic gonadotropin-releasing hormone in the ewe. Endocrinology, 94, 291-293.

Chamley W. A., Findlay J. K., Jonas H., Cumming I. A., Goding J. R., ig74 $b$. Effect of pregnancy on the FSH response to synthetic gonadotrophin-releasing hormone in ewes. $J$. Reprod. Fert., 37, 109-1 12.

Cognie Y., Hernandez-Barreto M., Saumande J., 1975. Low fertility in nursing ewes during the non breeding season. Ann. Biol. anim. Bioch. Biophys., 15, 329-343.

Cognie Y., Pelletier J., 1976. Preovulatory L.H release and ovulation in dry and lactating ewes after progestagen and PMSG treatment during anoestrum. Ann. Biol. anim. Bioch. Biophys., 16 (in press). 
Cooper K. J., Fawcett C. P., McCann S. M., 1973. Variations in pituitary responsiveness to luteinizing hormone releasing factor during the rat oestrous cycle. J. Endocr., 57, 187-188.

Cotta Y., Terqui M., Pelletier J., Courot M., 1975. Testosterone et LH plasmatiques chez l'Agneau de la naissance à la puberté. $\quad C . R$. Acad. Sci., 280, Ser. D, 1473-1476.

Cumming I. A., Brown J. M., Blockey M. A. de B., Winfield G. G., Baxter R., Goding J. R., 1971. Constancy of interval between $\mathrm{LH}$ release and ovulation in the ewe. $J$. Reprod. Fert., 24, I34-I35.

Cumming I. A., Buckmaster J. M., Cerini J. C., Cerini M. E., Chamley W. A., Findlay J. K., Goding J. R., I972. Effect of progesterone on the release of luteinizing hormone induced by a synthetic gonadotrophin-releasing factor in the ewe. Neuroendocrinology, 10, 338-348.

Debeljuk L., Arimura A., Schally A. V., $1972 a$. Effect of testosterone and estradiol on the LH and FSH releases induced by $\mathrm{LH}$-releasing hormone (LH-RH) in intact male rats. Endocrinology, 90, $1578-1581$.

Debeljuk L., Arimura A., Schally A. V., $1972 b$. Effect of estradiol and progesterone on the $L H$ release induced by $\mathrm{LH}$ releasing hormone in intact diestrous and anestrous ewes. Proc. Soc. exp. Biol. Med., 139, 774-777.

Debeljuk L., Arimura A., Schally A. V., i973a. Stimulation of release of FSH and LH by infusion of L.H-RH and some of its analogues. Neuroendocrinology, 11, $13^{0-1} 3^{6 .}$

Debeljuk L., Arimura A., Schally A. V., I973 b. Effect of estradiol on the response to LH-RH in male rats at different times after castration. Proc. Soc. exp. Biol. Med., 143, I I64-rI67.

Debeljuk L., Vilchez-Martinez S. A., Arimura A., Schally A. V., 1974. Effect of gonadal steroids on the response to LH-RH in intact and castrated male rats. Endocrinology, 94, I5I9-1524.

Ellendorff F., Pomerantz D. N., Elsaesser F., Parvizi W., Smidt D., König A., ig73. Response of plasma LH in male pigs to synthetic LH/FSH-RH. Acta. Endocr., 72, Suppl., 173, 83 (abstr.).

Findlay J. K., Buckmaster J. M., Chamley W. A., Cumming I. A., Hearnshaw H., Goding J. R. 1973. Release of luteinizing hormone by oestradiol-17 $\beta$ and a gonadotropin releasing hormone in ewes affected with clover disease. Neuroendocrinology, 11, 57-66.

Fink G., Gennser G., Liedholm P., Thorell J., Mulder J., 1974. Comparison of plasma levels of luteinizing hormone-releasing hormone in men after intravenous or intranasal administration. J. Endocr., 63, 351-360.

Foster D. L., Cook B., Nalbandov A. V., 1972. Regulation of luteinizing hormone (LH) in the fetal and neonatal lamb. Effect of castration during the early postnatal period on levels of LH in sera and pituitaries of neonatal lambs. Biol. Reprod., 6, 253-257.

Foster J. P., CRighton D. B., 1974. Luteinizing hormone (LH) release after single injections of a synthetic LH-releasing hormone (LH-RH) in the ewe at three different reproductive stages and comparison with natural $\mathrm{LH}$ release at oestrus. Theriogenology, 2, 87-100.

Galloway D. B., I973. The response of the ram to synthetic luteinizing hormone releasing factor (LH-RH) injection. J. Reprod. Fert., 35, 601. (abstr.).

Galloway D. B., Pelletier J., I974. Influence of age on the pituitary response of male lambs to synthetic LH-RH injection. Horm. Metab. Res., 6, 240-24I.

Galloway D. B., Pelletier J., I975. Luteinizing hormone release in entire and castrated rams following injection of synthetic luteinizing hormone releasing hormone and effect of testosterone propionate pre-treatment. J. Endocr., 64, 7-16.

Galloway D. B., Cotta Y., Pelletier J., Terqui M., I974. Circulating luteinizing hormone and testosterone response in rams after luteinizing hormone releasing hormone treatment. Acta. Endocr., 77, I-9.

Garnier D. H., Terqui M., Pelletier J. Plasma LH and testosterone in castrated rams following testosterone or testosterone propionate treatments. J. Reprod. Fert. (submitted for publication).

Gay V. L., Dever N. W., 1971. Effects of testosterone propionate and estradiol benzoate alone or in combination on serum $\mathrm{LH}$ and FSH in orchidectomized rats. Endocrinology, 89, 161-168.

GaY V. L., Niswender G. D., Midgley A. R., 1970. Response of individual rats to one or more injections of hypothalamic extract as determined by radioimmunoassay of plasma LH. Endocrinology, 86, I305-I312.

Goding J. R., Catt K. J., Brown J. M., Kaltenbach C. C., Cumming I. A., Mole B. J., i969. Radioimmunoassay for ovine luteinizing hormone. Secretion of luteinizing hormone during estrus and following estrogen administration in the sheep. Endocrinology, 85, 133-142.

Golter T. D., Reeves J. J., O'Mary C. C., Arimura A., Schally A. V., ig73. Serum LH levels in bulls treated with synthetic luteinizing hormone-releasing hormone (LH-RH/FSH-RH). $J$. Anim. Sci., 37, I23-127.

Hilliard J., Schally A. V., Sawyer C. H., r97I. Progesterone blockade of the ovulatory response to intrapituitary infusion of LH-RH in rabbits. Endocrinology, 88, 730-736.

Hooley R. D., Baxter R. W., Chamley W. A., Cumming I. A., Jonas H. A., Findlay J. K., 1974. FSH and $\mathrm{LH}$ response to gonadotropin releasing hormone during the ovine estrous cycle and following progesterone administration. Endocrinology, 95, 937-942. 
Hopkinson C. R. N., Pant H. C., Fitzpatrick R. S., 1974. Release of LH and FSH in the normal intact ram by synthetic $\mathrm{L} . \mathrm{H}-\mathrm{RH}$ and the effect of pretreatment with testosterone propionate. $J$. Reprod. Fert., 39, I $35-139$.

JAFFE R, KEYE W. R., 1974. Estradiol augmentation of pituitary responsiveness to gonadotropin releasing hormone in women. J. Clin. Endocr. Metab., 39, 135-139.

JENKIN G., HEAP R. B., I974. The lack of response of the sheep pituitary to LH-RH stimulation in gestation and early lactation; the probable role of progesterone. J. Endocr., 61, XII-XIII (abstr.).

Jonas H. A., Salamonsen L. A., Burger H. G., Chamley W. A., Cumming I. A., Findi.Ay J. K., GoDiNG J. R., 1973. Release of FSH after administration of gonadotrophin releasing hormone or estradiol to the anestrous ewe. Endocrinology, 92, 862-865.

Jones H. G. E., Boyns A. R., I974. Effect of gonadal steroids on the pituitary responsiveness to synthetic luteinizing hormone releasing hormone in the male dog. J. Endocr., 61, I23-I3I.

Kaltenbach C. C., Dunn T. G., Kiser T. E., Corah 1. R., Akbar A. M., Niswender G. D., 1974. Release of FSH and $\mathrm{LH}$ in beef heifers by synthetic gonadotrophin releasing hormone. J. Anim. Sci., 38, 357-362.

Kastin A. J., Gual C., Schally A. V., 1972. Clinical experience with hypothalamic releasing hormone and other hypophysiotropic releasing hormones. Rec. Progr. Horm. Res., 23, $201-217$.

Kelch R. P., Jenner M. R., Weinstein R., Kaplan S. L., Grumbach M. M., ig72. Estradiol and testosterone secretion by human, simian and canine testes, in males with hypogonadism and in male pseudo hermaphrodites with the feminizing testes syndrome. J. Clin. Invest., 51, 824-830.

Keiler P. J., Gerber C., I973. Effect of the sublingual, intravenous and intramuscular administration of synthetic LH-releasing hormone in the human. Horm. Metab. Res., 5, 64-65.

KEYE W. R., JAFFE R. B., 1974. Modulation of pituitary gonadotropin response to gonadotropin releasing hormone by oestradiol. J. Clin. Endocr. Metab., 38, 805-81o.

Kittok R. J., BRitt J. H., Convey E. M., I973. Endocrine response after Gn-RH in luteal phase cows and cows with ovarian follicular cysts. J. Anim. Sci., 37, 985-989.

Kley H. K., Wielgelmann W., Nieschlag E., Solbach H. G., Zimmermann H., KrüsKEMPER H. L., 1974. LH, FSH and testosterone in plasma following LH-RH infusion. A combined test for pituitary and leydig cell function. Acta. Endocr., 75, 417-427.

Kulkarni P. N., Simpson A. A., McLeod S. M., 1974. LH response to LH-releasing hormone and its relationship to $17 \beta$-estradiol in ovariectomized rats and anovulatory women. J. Clin. Endocr. Metab., 39, 352-355.

Land R. B., Pelletier J., Thimonier J., Mauleon P., I973. A quantitative study of genetic differences in the incidence of oestrus, ovulation and plasma iuteinizing hormone concentration in the sheep. J. Endocr., 58, 305-317.

Legan S. J., GaY V. L., Midgley A. R., I973. LH release following steroid administration in ovariectomized rats. Endocrinology, 93, 78I-785.

LEwIS P. E., Bolt D. J., INSKEEP E. K., 1974. Luteinizing hormone release and ovulation in anoes trous ewes. J. Anim. Sci., 58, I197-1203.

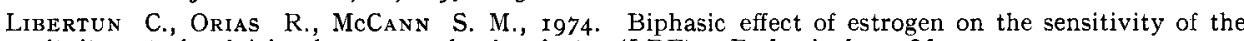
pituitary to luteinizing hormone releasing factor (LRF). Endocrinology, 94, I094-I roo.

Matsuo H., Baba Y., Nair R. M. G., Arimura A., Schally A. V., ig7i. Structure of the porcine LH and FSH releasing hormone. The proposed amino acid sequence. Biochem. Biophys. Res. Comm., 43, 1334-1339.

Mongkonpunya K., Hafs H. D., Convey E. M., Oxender W. D., Louis T. M., I974. Luteinizing hormone release by gonadotropin releasing hormone before and after castration in bulls. Proc. Soc. exp. Biol. Med., 147, 873-877.

Moss R. L., McCANN S. M., 1973. Induction of mating behavior in rats by luteinizing hormone releasing factor. Science, 181, I77-I79.

Niswender G. D., I969. Changes in serum LH following injection of hypothalamic extract in sheep. J. Anim. Sci., 29, r95 (Abstr.).

Niswender G. D., Reichert L. E., Zimmerman D. R., I97o. Radioimmunoassay of serum level of luteinizing hormone throughout the estrous cycle in pigs. Endocrinology, 87, 576-588.

PANT H. C., WARD W. R., 1974. Effect of intravenous infusion of oestradiol $I 7 \beta$ with and without prior progesterone treatment on the plasma luteinizing hormone and follicle stimulating hormone concentrations in anoestrous ewes. $J$. Endocr, , 61, V-VI.

Pelletier J., 1968. Élévation du taux de LH dans le plasma sanguir du bélier après castration. Ann. Biol. anim. Bioch. Biophys., 8, 313-315.

Pelletier J., I970a. Influence de la testostérone sur la sécrétion et la libération de l'hormone lutéinisante (LH) chez le mâle. Coll. nat. Centr. nat. Rech. Sci., nº 927, J. Benort and C. Kordon Ed., 329-337.

Pelletier J., I970 $b$. Mode of action of testosterone propionate on the secretion and release of luteinizing hormone (LH) in the castrated ram. Acta. Endocr., 63, 290-298.

Pelletier J., 1971. Influence du photoperiodisme et des androgènes sur la synthèse et la libération de LH chez le Bélier. Thèse Doc. Sci. University of Paris. $243 \mathrm{p}$.

Pelletier J., I974a. Decrease in the pituitary response to synthetic LH-RF in castrated rams following testosterone propionate treatment. $J$. Reprod. Fert., 41, 397-402. 
Pelletier J., I974 b. Influence de la lactation sur la décharge préovulaire de $\mathrm{LH}$ induite par l'injection de LRF synthétique chez la Brebis durant la période d'anoestrus saisonnier. $C$. $R$. Acad. Sci., Paris, Ser. D, 279, I79-182.

Pelletier J., Ortavant R., ig72. Effet du propionate de testostérone sur la libération de LH chez le Béiier : mise en évidence d'un double mécanisme de rétroaction. C. R. Acad. Sci., D, 275, 2037-2040.

Pelletier J., Ortavant R., I975. Photoperiodic control of LH release in the ram II light-androgen interaction. Acta endocr., 78, 442-450.

Pelletier J., Signoret J. P., r97o. Influences respectives de l'oestradiol et de la progestérone sur la décharge de LH dans le sang de la Brebis castrée. L'inhibition de l'ovulation, éd. Masson et Cie, $215-223$.

Pomerantz D. K., EllendorfF F., Elsaesser F,, 1974. Plasma LH changes in intact adult, castrated adult and pubertal male pigs following various doses of synthesic luteinizing hormone releasing hormone. Endocrinology, 94, 330-335.

Radford H. M., Wallace A. L., Wheatley I. S., I970. LH release, ovulation and oestrus following the treatment of anoestrous ewes with ovarian steroids. J. Reprod. Feri., 21, 371-372.

Rebar R., Yen S. S. C., Van Denberg G., Naftolin F., Ehara Y., Englom S., Ryan K. J., Rivier J., Amoss M., Guillemin R., 1973. Gonadotropin responses to synthetic LRF. Doses response relationship in Men. J. Clin. Endocr. Metab., 36, 10-16.

Reeves J. J., Arimura A., Schally A. V., r97o. Studies on dose response relationship of luteinizing hormone releasing hormone (LH-RH) in sheep. J. Anim. Sci., 31, 933-936.

Refves J. J., Arimura A., Schally A. V., I97I a. Pituitary responsiveness to purified luteinizing hormone releasing hormone (LH-RH) at various stages of the estrous cycle in sheep. J. Anim. Sci., 32, I 23-I 26.

Reeves J. J., Arimura A., Schally A. V., I971 b. Changes in pituitary responsiveness to luteinizinghormone releasing hormone (LH-RH) in anoestrous ewes pretreated with estradiol benzoate. Biol. Reprod., 4, 88-92.

Reeves J. J., Arimura A., Schally A. V., Kragt C. L., Beck T. W., Casey J. M., ig72. Effect of synthetic luteinizing hormone/follicle-stimulating hormone releasing hormone (LH-RH/FSH-RH) on serum LH, serum FSH and ovulation in anoestrous ewes. J. Anim. Sci., 85, 84-89.

Reeves J. J., TaRnaysky G. K., Chakraborty P. K., I974. Serum LH in ewes treated with synthetic luteinizing hormone releasing hormone/follicle stimulating hormone-releasing hormone(LH-RH/FSH$\mathrm{RH})$ at three periods of anestrus. J. Anim. Sci., 38, 369-373.

Rippel R. H., Moyer R. H., Johnson E.S., Mauer R. E., i974. Response of the ewe, to synthetic gonadotropin releasing hormone. J. Anim. Sci., 38, 605-612.

Robinson T. J., Moore N. W., Iindsay D. R., Fletcher I. C., Salamon S., ig7o. Fertility following synchronization of oestrus in the sheep with intra-vaginal sponges. I. Effects of vaginal douche, supplementary steroids, time of insemination, an numbers of dilution of spermatozoa. Aust. J.agric. Res., 21, 767-781.

Root A. W., Duckets G. E., 1973. In vivo and in vitro effects of synthetic luteinizing hormonereleasing hormone (LH-RH) upon the secretion of luteinizing hormone (LH) and follicle stimulating hormone (FSH) in intact and castrated fed and starved adult male rats. Proc. Soc. exp. Biol. med, 144, 30-33.

Roth J. C., Kelch R. P., Kaplan S. L., Grumback M. M., 1972. FSH and LH response to luteinizing hormone-releasing factor in prepubertal and pubertal children, adult males and patients with hypogonadotropic and hypergonadotropic hypogonadism. J. Endocr. Metab., 35, 926-930.

SANDOW J., BABEJ M., r973. Effects of chronic treatment with $\mathrm{LH}-\mathrm{RH}$ in rats and in golden hamster. Acta. Endocr., 73, Suppl., 177, 297 (abstr.).

Schally A. V., Arimura A., Kastin A. J., Matsuo H., Baba Y., Redding T. W., Nalr R. M. G., DeBELJUK L., I97I. Gonadotropin releasing hormone : one polypeptide regulates secretion of luteinizing and follicle stimulating hormone. Science, 173, го36-1038.

Schams D., Höfer F., Schallenberger E., Hartl M., Karg M., 1974. Pattern of luteinizing hormone ( $\mathrm{LH})$ and follicle stimulating hormone (FSH) in bovine blood plasma after injection of a synthetic gonadotropin releasing hormone (GH-RH). Theriogenology, 1, I37-I5I.

Segerson E. C. Jr, Ulberg L. C., Martin J. E., Fellows R. E., 1974. Fertility in ewes treated with luteinizing hormone releasing factor. Proc. Soc. exp. Biol. Med., 146, 5r8-52I.

Symons A. M., Cunningham N. F., Saba N., 1974. The gonadotrophic-hormone response of anoestrous and cyclic ewes to synthetic luteinizing hormone releasing hormone. J. Repr. Fert., 39, II-2I.

Terqui M., Garnier D. H., Cotta Y., Rovger Y. A., I974. Dynamics of testosterone and oestradiol-I7 $\beta$ plasma concentrations in sheep. J. Steroid Biochem., 5, 379 (Abstr.).

Thimonier J., Cognie Y., r97r. Accélération des mises-bas et conduite de l'élevage chez les ovins. Bull. Tech. Inform. Minist. Agric., 257, I87-196.

Thimonier J., Pelletier J., 197i. Différences génétiques dans la décharge ovulante (LH) chez les brebis de race Ile-de-France : relations avec le nombre d'ovulations. Ann. Biol. anim. Bioch. Biophys., $11,559-567$.

Thimonier J., Terqui M., Pelletier J., I974. Plasma estradiol and progesterone levels and pituitary responsiveness to $\mathrm{LRH}$ in the ewe. J. Steroid Biochem., 5, 388 (Abstr.). 
Thompson I. E., Arfania J., Taymor M. L., 1973. Effects of estrogen and progesterone on pituitary response to stimulation by luteinizing hormone releasing factor. J. Clin. Endocrinol. Mctab., 37, I52-I 55 .

Van Dieten J. A. M. J., Steijsiger J., Dullaart J., Van Rees G. P., 1974. The effect of estradiol benzoate on the pituitary reponsiveness to LH-RH in male and female rats. Neuroendocrinology, 15, I $82-188$.

Vilchez-Martinez J. A., Arimura A., Debeljuk I., Schally A. V., 1974. Biphasic effect of estradiol benzoate on the pituitary responsiveness to LH-RH. Endocrinology, 94, I302-1303.

Watson J. T., Krulich L., McCann S. M., 1974. Effect of crude rat hypothalamic extract on serum gonadotropin and prolactin levels in normal and orchidectomized male rats. Endocrinology, 88, I412-14I8.

Yen S. S. C., Rebar R., Vandenberg G., Naftolin i., Ehara Y., Engblom S., Ryan K. J., BENIRSChe K., I972 a. Synthetic luteinizing hormone-releasing factor. A potent stimulator of gonadotropin release in man. J. Clin. Endocrinol. Metab., 34, I108-1 111 .

Yen S. S. C., VAndenberg G., Rebar R., Ehara Y., I972 b. Variation of pituitary responsiveness to synthetic LRF during different phases of the menstrual cycle. J. Clin. Endocr. Metab., 35, 93I-934.

Zarate A., Canales E. S., Schally A. V., Ayala-Valdes L., Kastin J., i973. Successful induction of ovulation with synthetic luteinizing hormone-releasing hormone in anovulatory infertility. Fertil. Steril., 23, 672.

Zolman J., Convey E. M., Britt J. H., Hafs H. D., 1973. Release of bovine luteinizing hormone by purified porcine and synthetic gonadotropin releasing hormone. Proc. Soc. exp. Biol. Med., 142, I89-I93.

Zolman J., Convey E. M., Britt J. H., 1974. Relationship between the luteinizing hormone response to gonadotropin releasing hormone and endogenous steroids. J. Anim. Sci., 39, 355-359. 